\title{
„Die deutsche Muse wagst Dir, Herr, ein Lied zu singen". Stanisław August Poniatowski w poezji kurlandzkiej
}

Aleksandra Norkowska 
nAPPS Seria XI 2005

\section{Aleksandra Norkowska}

\section{„Die deutsche Muse wagst Dir, Herr, ein Lied zu singen”. Stanisław August Poniatowski w poezji kurlandzkiej}

\footnotetext{
Z
} zapisków z podróży po stanisławowskiej Polsce, które pozostawili po sobie cudzoziemcy, wylania się portret Stanisława Augusta skreślony najczęściej z sympatią. Odwiedzający Rzeczpospolitą pozytywnie wypowiadali się o Poniatowskim jako o monarsze usilnie dążącym do naprawy państwa. Nie tylko wnikliwi obserwatorzy dostrzegali, iż trudności, z jakimi borykal się król-reformator, wynikaly zarówno ze starcia majestatu z wolnościowymi dążeniami szlachty, jak i z niewprawnej dyplomatycznej taktyki polskiego władcy. Wyrażano uznanie dla jego miłego obejścia, erudycji, umilowania sztuk i nauk, a jednocześnie wskazywano na rozrzutność i chwiejność charakteru. Joseph Marshall, angielski kupiec, podkreślał królewską bezradność: ,jest człowickiem o szerokich i współczesnych poglądach i ma szczere patriotyczne wspólczucie dla nieszczęść swego kraju, ale zupehnie nie jest w stanie im zapobiec"!.

Wśród pamiętnikarskich relacji spotykanny też obraz Stanisława Augusta stworzony przez Elisę von der Recke. W czasie Sejnu Wielkiego przebywata ona na polskim dworze, towarzysząc swej siostrze, księżnej kurlandzkiej, w wypetnianiu jej politycznej misji w Warszawie. Obie damy przybyly z Mitawy² (obecnie Jegławy), siedziby książąt dzie-

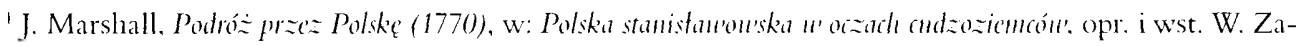
wadzki, t. 1, Warszawa 1963, s. 322.

? Wspomniany juz Anglik podróżujący z Inflant do Polski. wskazując na naturalne bogactwa Kurlandii. zawarl w swym dzicnniku i takic oto spostrzeżenia (ihidem, s. 3(1)9): .Za szczęśliwych czasów książąt kurlandzkich, kiedy dynastia Kettlerów spokojnic panowala nad krajem i wszystkimi miastami ksiçstwa, nicpustoszonymi przez Szwedów i Rosjan. Mitawa byla znacznym i piçknym miastem i miała blisko piçtnaścic tysięcy mieszkańców, obecnie zaś nie liczy więcej jak dzicwięć tysięcy. Jest to jeszcze dziś przyjemne miasto, dobrze zbudowane, gdzie w hadnym palacu książ̧cym jest niby dwór, ze strażą przyboczną i silną zawsze zalogą". 
dzicznego Księstwa Kurlandii i Semigalii, które od 1569 roku stanowiło wspólne lenno Polski i Litwy ${ }^{3}$. Do czası wojny północnej, gdy wojska rosyjskie zajęły tę cześć Inflant, cieszyło się ono wielką autononią. W okresie rozkwitu posiadało nawet kolonie w Afrycet. Po 1711 rokı, kiedy to car Piotr Wielki wydal córkę Iwana V - Annę Iwanowną za Fryderyka Wilhelma Kettlera, decydıjącą rolę zaczęla odgrywać Rosja. Sytuacja skomplikowała się jeszcze bardziej, gdy po nagłej śmierci Fryderyka miejsce u boku Anny zajął rodowity Kurlandczyk, Ernest Johann Bülıren (Biron). Jego to w 1737 roku August III mianowat dziedzicznym księciem Kurlandii po śmierci Ferdynanda, ostatniego potomka mistrza zakonu inflanckiego, Gotlarda. Obalony cztery lata późnicj i zesłany na Syberię przez Elżbietę, ówczesną władczynię Rosji, pozbawiony zostal również księstwa. Wówczas to August III wykorzystal sytuację i w 1759 roku nadal lenno swojemu synowi Karolowi Wettynowi 5 .

${ }^{3}$ W ostatuich latach wzroslo zainteresowanie dzicjanni tej części dawnych lnflant, czego dowodem jest miçdzy innymi zorganizowanic dwóch miçdzynarodowych konferencji nankowych w lotewskim micścic Ventspils (pol. Widawa): Dzicje Księstu'a Kurlandii i Semigulii - stan badan i perspekty'u'y' badau'cze (1-3 czerwo 2000): DEieje Ksig̨stu'a Kurlandii i Semigalii - spoteczenstu'o, polityka, kultura (10)-11 czerwca 2004). Pokłosiem pierwszego spotkania jest zbiór artykułów, inicjujący seriç wydawniczą ..Ventspils muzcja raksti”. Kurrzeme's un Ze'mgales herrogisfe - pétniecibã sasmiegtais un perspektī'as, wyd. A. Vijups, Riga

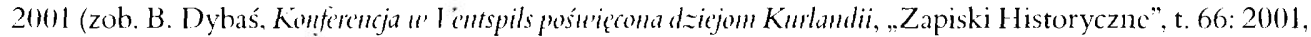

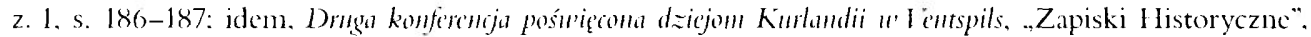
t. 70: 2005, z. 1. s. 189-190). Rezultatem wspólpracy historyków lotewskich, nicmicckich i polskich jest takze tom Das Herzongtum Kunlund 1561-1795. I erfassung, I I'irtschaft, Gisellschaft, Bd. 2, hrsg. von E. Oberländer. Lünenberg 200)I (zob. recenzję J. Wijaczki, .Zapiski I Iistoryczne”, t. 69: 2004, z. 1, s. 156-160).

+ Mowa tu o kurlandzkich koloniach zalożonych przez Jakuba Kettlera, księcia Kurlandii, w polowie XVII wicku w Gambii i na Nowych Antypodach. Zob. E. A. Micrzwa, Szesnastoureczlal Rzeczpospolita kolemialnq metropolin?? "Zeszyty Naukowe Wyższej Szkoly Pedagrogiczucj w Olsztynie” 8: Prace Historyezlle, z. 1. red. T. Filipkowski. Olsztyn 1997. s. 21-26.

"Nicchçtny stosunck Familii do królewicza Karola wsponina ostatni polski wadca (Stanisław August Poniatowski, Pamięmiki, opr. Z. Góralski. t. 3. Warszawa 1995, s. 10-11) w ten oto sposób: „Na skutck pewnych okoliczności stalem siç potrzebnicjszy u boku Augusta III niż na dworze rosyjskim. Przyczyniła siç do tego sprawa ksiçstwa Kurlandii. Biron i jego rodzina marnicli w rosyjskim wiçzicniu od dziesięciu lat. co dla ksiçstu'a stanowilo wiclka niedogodnośc, a w dodatku podważalo prawa suwerenne Polski. Na nasze wiclokroć ponawiane reklamacje Rosja odpowiadała wymijająco. August lll uznal, że nadeszła pora. aby zakrzątnąć się wokót interesów swego ukochanego syna, Karola. Od carycy Elżbiety wydobyl liczne zapewnicnia. żc rosyjska racja stanı nic pozwala, aby ksiąz̨̧ Biron wraz z rodziną odzyskal kicdykolwick wolność. Król poczul siẹ na silach. aby po zerwaniu scjmu z 1756 r. przedstawić senatowi Polski do rozważenia. czy lemna Kurlandii nic można by uznać za wakujące i nadać go ponownie? Zdaniem mojego ojca i wujów. Bironowi wyrządzono zbyt jaskrawą krzywdę, a uzurpowanie sobic przez Rosjç prawa do decydowania o sukcesji kurlandzkicj z pominiçciem Birona, zlej pamiçci regenta cesarstwa rosyjskiego, godzilow honor Polski. Wreszcic. patco connenta zobowiązywaly Augusta III do zasiçgania waznych opinii trzech stanów Kurlandii zgromadzonych w scjmic. Senutus comsilium nic wystarczało. Poza tym, nadwyrężone mocno zdrowic carycy Elżbicty pozwalalo przypuszczać. że Biron whrótce opuści więzicnic i stanie się nicbezpiecznym rywalem dla królewskiego syna. Racji tych nic wziçto pod uwagę. Zdecydowana wiçkszość scnatu glosowala w grudniu 1758 r. wedle życzenia króla. 9 stycznia 1759 r. król uroczyście z wiclką pompą nadal swemu synowi (...) księstwo Kurlandiï. 
Kilka lat później (w roku 1763) Katarzyna II osadziła Birona na miejscu królewicza, a Sas zmuszony zostal do opuszczenia Mitawy: od tej chwili kraj ten znajdowal siç faktycznie pod zwierzchnictwem Rosji.

W czasie gdy Elisa von der Recke utrwalała w dzienniku codzienne życie warszawskiego dworu, na czele Księstwa stal od ponad dwudziestu lat syn Ernesta, Piotr. Celem pobytu Dorothei Biron (ur. von Medem) w stołecznym mieście było pilnowanie interesów męża; na sejmie rozstrzygała się włánie kwestia lenna kurlandzkiego. Księżna zapoznała króla z projektem sukcesji, ponadto jej polityczna misja wynikała z niepokojów wewnętrznych, a dotyczyła sporu szlachty i mieszczan z Piotrem Bironem". Delegaci pierwszego z wymienionych stanów pragnęli wyłamać się spod zwierzchności Polski, a drudzy z kolei, zapewniając polskiego króla o swej wierności, protestowali przeciwko uszczupleniu własnego samorządu. Wyłoniona w 1792 roku deputacja uchwaliła między innymi ściślejsze powiązania Kurlandii z Polska ${ }^{7}$, a uchwalona przez Sejm deklaracja w sprawie miast kurlandzkich powtarzala postanowienia sejmu rozbiorowego z lat 1773-1775.

Siostra Bironowej jawi się jako osoba, którcj na sercu leży dobro ojczyzny. Sprzeciwia się propozycji wysuniçtej przez mieszczan, aby mogli procesować się ze szlachtą w Warszawie: „zepsułoby to nasz charakter narodowy - pisze - a jeszcze więcej pieniędzy odplywatoby z Kurlandii do Warszawy, dla mieszczaństwa zaś bylby to podarek, który możua by przyrównać do puszki Pandory" ". Podkreślając niezwykłą gościnność, z jaką spotykały się na polskim dworze", nie omieszkala jednak przy okazji zganić Polaków za brak gospodarności i nieustanne oddawanie się przyjemnościom; ze szczególną dezaprobatą przygląda się marnotrawieniu czasu przez arystokrację, której jedynym zajęciem był codzienny udział w stołecznych przyjęciach i balach. W swym dzienniku wicle miejsca poświęca Stanislawowi Augustowi; nie pisze o nim inaczej, jak tylko o „naszyn” królı. Wielokrotne użycie tego zaimka dzierżawczego świadczy w sposób nader widoczny o poczuciu więzi z monarchą Polakiem. Stanisław August musial wywrzeć na niej niezwykle wrażenie, niejednokrotnie opisuje władcę jako „dobrego”, „laskawego” i „miłego”. Najwiçkszą dla niej przyjemnością zdaje się być przebywanie z Poniatowskim, gdyz ... towarzystwie naszego dobrego króla

\footnotetext{
"W artykule przewijać się będą nazwiska reprezentantów każdego ze stanów, politycznych opozycjonistów: Friedricha Schulza. Brandenburczyka, który związany ze środowiskiem mieszczaniskim wystẹpowal przeciw przywilejom szlachty reprezentowancj przez Karla I Ieykinga. Ten z kolci 17 hitego 179/ roku zadeklarowal wierność szlachty kurlandzkicj dla Rzeczypospolitcj. Zub. K. Zicnkowska. Z dziejón miast

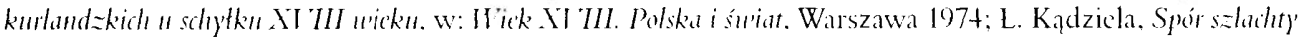

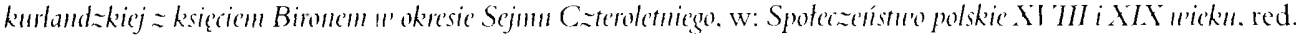
J. Leskicwiczowa. Warszawa 1987.

Zob. W. Zawadzki. przyp. 142 do: K. I I. von I- Icyking. Ilspommicmin z ostutnich lut Polski i Kunlandii 17.52-1796, w: Polska stamistau'uuskia... op. cit., s. 859 (wydanic polskic jest wersją skrócona panniçtników).

${ }^{\wedge}$ E. von der Recke, Na polskim durore króle'uskim, w: ibidem, s. 258.

"Stanistaw August byl pod urokicm piçkncj ksiçżncj kurlandzkicj i adorowal Bironową w czasic jej pobytu w Warszawic.
} 
godziny mijają przyjemnie i szybko, i nawet Pani Podoska staje się znośniejsza, gdy można napawać się spojrzeniem naszego ludzkiego króla"||". Po ponad dwustu latach wydaje się mało zasadne pytanie, czy epitet „ludzki” wskazuje na naturę człowieka odznaczającego się przychylnością, wyrozumiałością, łagodnością, czy też autorka w tyın fragmencie wskazuje raczej na królewski urząd, podkreśla jego najwyższą pozycję w państwie. Lektura pamiętnika prowadzonego przez Kurlandkę pozwala dommiemywać, iż takie określenie króla świadczy bez wątpienia o życzliwości i przywiązaniu do króla.

Ale nie na ten ,ludzki” rys Poniatowskiego chciałabym zwrócić uwagę w tej części szkicu. Królewska postać urzekła też profesora historii w Academiae Petrina w Mitawie. Fryderyk Schulz, wspominając w Podrózach Inflantcz)'ka pierwsze spotkanie z Poniatowskim, zaznaczyl, iż trudno było poznać po nim, że kończy 61 lat. Włosy co prawda miał siwiejące,

ale skórę niepomarszczoną, twarz pelną, oko żywe i pełne ognia, a zarazem lagodności i dobroci (...). Ust piçkniejszych widzieć trudno. Glos jego bardzo czysty, lagodny i w rozmowie giętki, traci, gdy z wysileniem publicznie użyć go musi. (...) noga i stopa nadzwyczaj foremne i piękne. Trzyma się jeszcze po modziéńczenuı prosto"

Powróćmy do poezji. Tematem rozważan jest bowiem poetycki wizerunek Stanisława Augusta skreślony przez kurlandzką muzę. I ona, podobnie jak cudzoziemcy odwiedzający Polskę, zachwyciła się kilka lat wcześniej nonarszym spojrzeniem.

W 1788 roku Karol Fryderyk Aleksander von Holtey podarował królowi wierszowane życzenia urodzinowe, wydane drukiem w Mitawie przez oficynę J. E. Steffenhagena. Już w zwięzłym i skromnym exordinm, pozbawionym cech solemnis, bliżej nieznany poeta skierowal do wladcy te oto słowa:

\author{
Monarch! \\ Mit innigen Entziicke'n \\ Hängt noch mein . Aug'an Deinen Blicken (...)
}

(Monarcho!

Z gorącym zachwytem

moje oczy tkwią jeszcze w Twoim spojrzeniu [...]).

\footnotetext{
"Ibidem. s. 24).

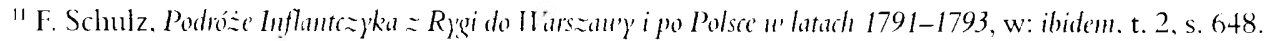

12 [K. F. A. von Holtey.] An seine Majestät den König. Den 17. Januar 1788, Mitan, J. E. Steffenhagen; egz. Biblioteki PAU-PAN w Krakowic sygn. 320, k. 23 t.
} 
Apologeta Poniatowskiego jest autorem jednego z niezliczonych okolicznościowych tekstów stanisławowskich uświetniających królewskie gale. Ta „monarsza” poezja (pełna skonwencjonalizowanych motywów), wspóltworzyła - wraz z architekturą okazjonalną, iluminacjami, festynami, koncertami oraz przedstawieniami teatralnymi — oprawę dni upamiętniających elekcję i koronację oraz urodziny i imieniny Stanisława Augusta Poniatowskiego ${ }^{13}$. Jeszcze i dzisiaj spotykany wiele literackich świadectw dowodzących, że uroczystości rocznicowe obchodzono zarówno w Warszawie, jak i w najdalszych zakątkach Rzeczypospolitej.

17 stycznia nie zapominano o urodzinach polskiego monarchy także w Księstwie Kurlandii i Semigalii, którego terytorium, jak podaje Zygmunt Gloger, ,przypominało ksztalt nieregularnego klina, dlugiego prawie mil 60, rozszerzonego nad Bałtykiem, z ostrym wierzchotkiem u miasteczka Drui nad Dźwiną. Północną jego granicę stanowiła Zatoka Ryska i cała szerokość Intlant z rzeką Dźwiną; południową Żmudź i Litwa, a zachodnią Baltyk z dwoma portani: Windawą i Libawą"lt.

Wiersz Holteya należy do grupy stereotypowych wypowiedzi pochwalnych, które pisano najczęściej po polsku, następnie po lacinie, w języku francuskim, włoskim czy hebrajskim. Spod pióra niemieckojęzycznego twórcy wyszedl utwór, jakich w ówczesnym czasie wiele $^{15}$. Utrzymany w konwencji gemus demonstratir'mm - niepozbawiony wątków apologetycznych - przedstawia portret Stanislawa Augusta odmalowany zgodnie z oświeceniowymi wyobrażeniami idealnego władcy. To jedyny wśród monarchów, dobry i wielki czlowiek, który da narodowi szczęście i pokój. Opieka polskiego monarchy nad sztuką i nauką stała się jednym z głównych elementów naprawy państwa. Poniatowski przyczynił się również do rozwoju szkolnictwa i nauki w Kurlandii, podpisując między innymi akt erekcyjny stynnego gimnazjum klasycznego Academia Petrina, które powstało w 1775 roku w Mitawie. Szkola, mająca w pierwszych latach swego istnienia charakter wyższej uczelni, odgrywała dıżą rolę nie tylko na szczeblu lokalnym; uczęszczali do niej bowiem młodzi ludzie z różnych krajów Europy ${ }^{16}$. Wspomniany już Fryderyk Schulz uzyskat tam powołanie na stanowisko profesora historii za wstawiennictwem Elisy von der Recke (bywal w prowadzonym przez nią salonie literackim). Obowiązki objął od stycznia roku 1791, a rok później piastował już funkcję prorektora gimnazjum ${ }^{17}$. W swych pamiętnikach, zwracając uwagę

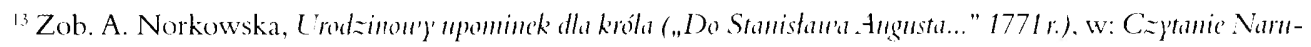
szeu'icza. Interpretacje, red. T. Chachulski. Wroclaw 20(0).

1+ Z. Gloger. Geografia historyezma ziem dan'nej Polski, Kraków 1900, s. 324.

${ }^{15}$ Por. anonimowy wiersz, równicż z 1788 roku. zatytulowany Dzion siedemnastego styenia, egz. Biblioteki Czartoryskich w Krakowic sygn. 938 IV, s. 255.

"W klasycystycznym gmachu szkoly mićści siç obecuic Muzeum 1 listorii Sztuki. W grudniu 2003 roku

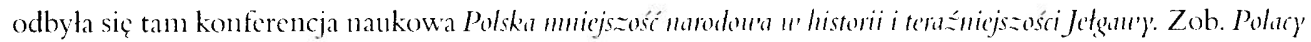
na Lotuice. .Alma Mater. Miesiçcznik Uniwersytetu Jagielloniskicgo”, 57-58/20)4.

17 Zob. Polski stounik biograficany, t. 36, Wrockaw 1995, s. +2.
} 
na troskę, jaką Poniatowski otaczał młode pokolenie, pisal, iż wprowadzona za jego panowania reforma edukacji otworzyła młodzieży szlacheckiej

źródla nowych wiadomości, do których ojcowie ich przystępu nie mieli. Wstąpiwszy na tron, zebrat do szkól na nauczycieli najzdolniejszych ludzi, jakich w kraju znaleźć tylko można, sprowadził też wielu doświadczonych z zagranicy. (...) Planem jego było wszakże powoli dać wygasnąć temu pokoleniu, a miejsca jego zapełnić młodzieżą wychowaną wedle zasad nowych, nie tylko wolną od zastarzałych przesądów i nadużyć, lecz również nowym nadużyciom oraz nieporządkom przeciwną, i reformom a zmianom popęd dać mogącą ${ }^{\text {Is. }}$.

W wielu szkolnych panegirykach przedstawiano Stanisława Augusta jako „ojca młodzi” i wzór godny naśladowania. I Ioltey widzi w nim człowieka, który „durch Sein schönes Leben / Die Weisheit und die Tugend lieben lehrt" [nczy swym pięknym życiem kochać mądrość i cnotę"]. Znany to laudacyjny argument. Kurlandzki twórca szczególne miejsce poświęcił mecenasowskiej dzialalności Poniatowskiego. Wiersz przynosi wizerunek króla otoczonego Gracjami i Muzami (.Ich sah v'on Grazien und Musen rund unngegeben”). Poetycki podarunek z dalekiej Mitawy przepełniony jest tęsknotą; Holtey z drżącym sercem wspomina przeszłe radości, które byly jego udzialem, gdy znajdował się w otoczeniu króla. Ten niemieckojęzyczny genetliakon, nawiązujący do antycznego utworu na dies natalis, przynosi konwencjonalną pochwałę samego dnia urodzin: „Heil Deinen Wonnetag in seinem Rosenkleid!” - poetycka wyobraźnia przybrała ten radosny dzień w różaną suknię.

Nie zabrakto też w analizowanym okazjonalnym panegiryku innych argumentów laudacyjnych. Poniatowski ukazany został jako król mądry, którego na polski tron wybrały niebiosa, ku — jak podkreśla autor — radości rodzaju ludzkiego. Kurlandzka muza przypomina również uczucie szczęścia, jakie po ogłoszeniu wyników elekcji towarzyszyło szlachcie zgromadzonej w podwarszawskiej Woli. Zabieg ten miał na celu wzmocnienie laudacyjnego tonu wypowiedzi, a przede wszystkim utrwalal pożądaną życzliwość słuchaczy (benenolentia). I Ioltey podjąl motyw tak często wykorzystywany w poezji elekcyjno-koronacyjnej i w późniejszych utworach prokrólewskich. Poniższe wykrzyknienie nadaje przy tym całej wypowiedzi charakter patetyczny:

Wie tönt won fern, hente, Jubel in mein Olır!

(Jak brzmi z oddali, jeszcze dzisiaj, radość w moich uszach!).

${ }^{14}$ F. Schulz, op. cit., s. 652-653. 
Oczywiście, Poniatowski przedstawiony został jako król, który zyskal akceptację całego narodu. Autor przemilczal, jak to uczyniono w wielu panegirykach, dramatyczną sytuację, jaka miała micjsce w okresie ostatniego interregmum, gdy stronnictwa, koterie i fakcje starały się przede wszystkim pozyskać jak najwięcej zwolenników i zdobyć względy Prus i Rosji. Wówczas właśnie trwał spór o Kurlandię, a „Familia” Czartoryskich, zrywając ostatecznie ze stronnictwem saskim, zaczynałą budować silną partię polityczną. Konflikt Petersburga z Dreznem o lenno Rzeczypospolitej rozwiązany zostal definitywnie w 1764 roku, gdy uległy Katarzynie byly stolnik litewski Stanisław Antoni Poniatowski, juz jako polski król, zatwierdził Birona w godności księcia.

Analizowany wiersz został napisany w na kilkanaście miesięcy przed rozpoczęciem Sejmu Wielkiego. W peroracji utworu laudator kieruje do króla niewychodzące poza stereotyp życzenia, aby dalsze lata jego „łagodnego” panowania przyniosły narodowi „szczęście i spokój”. Holtey, utożsamiając się ze zbiorowością, zapewnia, iż miłość, jaką darzy wladcę, jest też udziałem jego współziomków. W ten sposób tworzy się w utworze —- tak pożądany — podniosły nastrój sprzyjający gloryfikacji monarchy.

Słowa oddania, zapewniające o głębokim uczuciu plynącym prosto z serc Kurlandczyków, odnajdıjemy też w wierszowanym podarunku złożonym u królewskich stóp z okazji dnia imienin. Nadeszla pora, aby pochylić się nad interesującym panegirykiem, którego autorem jest Georg von Alten Bokum, przedstawiający się jako „adiutant generalny Jego Majestatu i pułkownik" "9 . Tekst został wydany 8 maja 1777 roku $^{20}$ w królewskiej drukarni Wawrzyńca Mitzlera de Kolof, na równo rok przed śmiercią Saksończyka. Środowisko niemieckie odegrało ważną rolę w życia intelektualnym Rzeczypospolitej. Jednym z inspiratorów dialogı obu kultur był wspommiany wydawca. Polski król docenił jego zasługi i na tym polı (byl on ponadto księgarzem, redaktorem, muzykologiem, lekarzem), odznaczając go medalem „Merentibus”. Warto tu przytoczyć opinię Mitzlera na temat czczych panegiryków: „pisarz schlebiający, a przy tym kłamca, nie przedstawia żadnej wartości”-21. W podobnym tonie utrzymane jest zakończenie imieninowego podarunku. Autor przywołuje mityczny

"[G. von Alten Bokum]. Den achten May' 1777 Jlalhes], als an dem frohen Namens-Fe'ste Ihere Majestät des

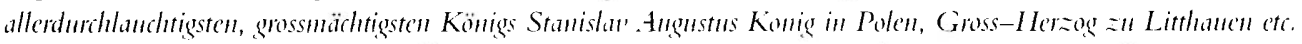
brache dieses Opfer der Trene und tiefster Ehrfurdit ein tre't gehorsunster Curländer..., sciner Majestät Generinl-Adjutant und Oberster. Warschatu, in der Mitzlerrischen Buchdr.: cgz. Biblioteki IBL PAN w Warszawic, sygn. XVIII.3.129. Możeny domnicmywać, żc byl on spowinowacony z Janem I fenrykiem von Alten Bokum (zmarlym ok. 1685 roku1), generałem wojsk koronnych i stolnikiem litewskim (1679), który nalezal do otoczenia Jana III Sobieskicgo i Jana Kazimicrza. Pochodzil on, jak podaje Polski stow'nik brograficzn' (t. 2. Kraków 1936, s. 246) .z nicmieckicj szlachty nadreńskicj. którcj jedna galąź przesicdliła się do Inflant w XV w. W polowic XV'll w. przenióst się z Kurlandii na Litwç i zalożyl nową galąź swej rodziny".

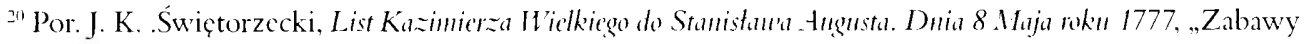
Przyjcmne i Pożytecznce" 1777 t. 15, cz. 2, s. 290-308: F. A. Naglowski, Serdeczne przj'món'iénie się Królon'i dinia 8 maja 1777. ibidem, s. 319-320.

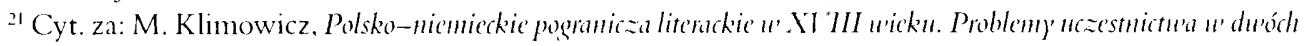
kulturach. Wroctaw 1998, s. 37. 
złoty wiek (ten motyw spaja caly utwór), kiedy powszechna była uczciwość i szczerość, a nie „Schmeicheley' und (...) Geschenke” (,pochlebstwa i [...] podarunki”).

Kurlandzki oficer podal w wątpliwość szczerość pisanych powszechnie panegiryków. Bokum co prawda chwyta za pióro okazjonalnie, ale jego poetycki upominek należy do grupy nielicznych wierszy, które zawierały refleksje ogólne. Już w tytule Die Opfer der Trene („Dar wierności”) dał wyraz swemu oddaniu. Przywoluje czasy, w których wyrażanie uczuć wolne bylo od nieszczerości i obludy. Taki był bowiem

Dic theure Pflicht der alte'n golden Zeit,

Wo Menschen unverstellt, sich nach dem Recht der Briider

Durch Wort und Handschlag echte Tren ge'u'e't

(Drogi obowiązek dawnego złotego wieku, gdy ludzie niezmienieni kierują się prawem bliźnich, podkreślają prawdziwą wierność przez słowo i podanie ręki).

Panegiryk whadcy ${ }^{22}$ stawial przed twórcą wymagania zakorzenione w tradycji gatunku. Wiersze rozpoczynano zazwyczaj od apostrofy do Muz, często łączono ją z toposem skromności, po czym następowała pochwała króla jako wzoru godnego naśladowania. Nie zapominano też o pochwale rodu, wykształcenia, cnoty i czynów. W tym utworze próżno szukać tego rodzaju argumentów laudacyjnych służących gloryfikacji Poniatowskiego. Wizerunek Stanisława Augusta jako wielkiego czlowieka i godnego milości władcy — autor zapewnia, iz

Ein Herz des eines Ihrer Sölune,

IVie aller, Dir gemidnet ist

(Serce jednęgo z synów tej ziemi,

Jak wszystkich pozostałych, bije dla Ciebie) -

- nie został wprost nakreślony. Wiersz cechuje niezwykła lojalność wobec króla i przywiązanie do jego osoby:

Nicht der redet allzeit schön, der angenehm erzählet?

Nur der Natur und in ihr Wahrheit licbt.

Der Ihr Geheis und seine Pfliditen

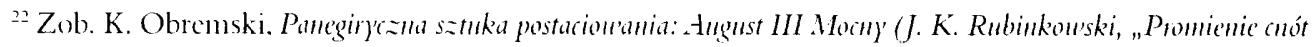
króleuskich..."), Toruń 2003. 
Nicht nach dem änssen Sohimmer misst;

Und diese Schuld tren zu entrichten,

Sie auch im Stanbe nicht vergisst.

(Nie ten pięknie mówi, którego opowiadanie wydaje się przyjemne,

Tylko ten, który ze swej natury miluje prawdę,

I który rozkazy Twoje i swoje obowiązki mierzy blaskiem zewnętrznym,

I który, aby spłacić swój dług,

Nie zapomina o nich nawet w tumanach kurzu1).

Słowom tym towarzyszy zapewnienie dochowania wierności monarsze.

Poetycki wizerunek Stanisława Poniatowskiego skreślony żołnierskim piórem przynosi nie tylko pochwałę władcy. Dotykany tı kwestii „cickawego fenomenu — na który zwrócił uwage Mieczysław Klimowicz - za jaki uznać można podziw Niemców z pogranicza dla walorów języka polskiego"23. W powszechnej opinii postrzegano język polski jako ten, który dzięki swej enfoniczności i semantyce zdolny jest udźwignąć wielką epikę. Bokum, świadomy tych walorów polszczyzny, zwracając się do Stanisława Augusta, zaznacza już we wstępie:

Die Deutsche' Muse u'agst Dir, Herr, cin Lied an singen

(Niemiecka muza ma odwagę tobie, Panie, zaśpiewać pieśí).

Kurlandczyk wskazuje na poezjowanie jako na jedną z dziedzin sztuki. Poeta drugiej połowy XVIII wieku, na wzór antycznego twórcy, zdaje sobie sprawę, że słowu wiązanemu towarzyszyć powinien śpiew lub gra na instrumentach. Gdy poezja i muzyka (wraz z tańcem) będą stanowić jedno ${ }^{2+}$, wiersz stanie się elementem tradycji twórczości heroicznej, a odbiorca obcował będzie z mitycznym światem epopei. Ale mylilibyśmy się, twierdząc, iż topos Muzy został tu polączony z tak często spotykaną afektowaną skrommością. Autor, przywołıjąc niemiecką siostrę helikońskiej bogini, świadomy jest jej niedoskonałości. Wymienia więc: „ihrer Rauhigkeit kein sanffer Ton gelingen” („szorstkość, która nie pozwala na lagodny ton”), „tun'ollkommme Tönc” (,niedoskonate dźwięki”) czy wreszcie ,der Schimmer fehlet, / Dén sonst der Reiz der höhern Spradikmnst giebr" (,brak blasku, / Któremu zwykle powabu dodaje jeszcze wyższa sztuka wymowy"). Bodaj to jedyny wśród napotkanych przeze mnie poetyckich świadectw epoki, dowodzących, iż niemieckojęzyczni twórcy zdawali sobie sprawę z panującej w Polsce negatywnej opinii o niedostatkach ich ojczystego języka w porównaniu z walorami polskiej mowy. Więcej przykładów wskazujących na po-

\footnotetext{
${ }^{23}$ M. Klimowicz, op. cit., s. 220.

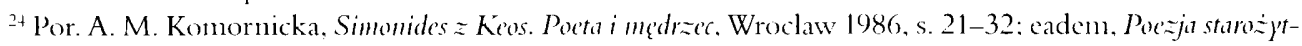
mej Grecji. IT Yhrance gatumki literackic, Lódź 1987.
} 
dziw Niemców z pogranicza odnajdıjenny w dziennikach z podróży, pamiętnikach czy też — najczęściej - w periodykach. Jan Samuel Richter pisał wręcz, iz polska mowa „jest tak samo melodyjna i dźwięczna jak włoska" ${ }^{25}$. Inny mieszkaniec Śląska, Jan Gottlieb Schummel, stwierdził wręcz, iż „żaden europejski język nie oddaje tak znakomicie ducha autorów lacińskich w przekladzie jak polski”. Z kolei Teodor Bauch z Torunia, który zapewniał, iż „bardzo kochał się w języku polskim”, w roku 1761 w przedmowie do pierwszego numeru „Patrioty Polskiego” przekonywal, że jest w nim „mnogość i bogactwo słów, i taka piękność i delikatność wyrażania”. Pozostawało to w kontraście do niewielkiego zainteresowania polskiego czytelnika literaturą niemiecką. W czasach stanislawowskich opinia Polaków o języku sąsiadów była zgola odmienna. W 1792 roku Piotr Świtkowski przyznawał później, iż w odróżnieniu od literatury francuskiej „hydziliśmy z pism wszelkich niemieckich, używaliśmy wyrazy, że to było deutcz [!], jakoby dając znać, że w Niemczech, co tylko piszą, musi być coś ociężatego, nieprzyjemnego"-26.

W sytuacji gdy powszechne było okazywanie wstrętu dla pozbawionej lekkości pióra literatury niemieckojęzycznej, utwór Bokuma, mimo że wydaje się aktem konwencjonalnej grzeczności, nie jest stereotypowym panegirykiem. Poeta-oficer, ośmielając się „śpiewać” o królı, wzbogaca wiersz o głçbszą refleksję. Z ıtworı wyłania się obraz oświeconego poddanego, a już to stać się mogło powodem zadowolenia królewskiego adresata. Przypomnę jeszcze, iż Stanisław August znał również język niemiecki (oprócz angielskiego, francuskiego, włoskiego, rosyjskiego czy łaciny) do tego stopnia, że - jak wspomina Schulz — „słysząc go mówiącego lub czytającego, można by go wziąć za rodowitego Wlocha lub Nienca"27.

Wśród okolicznościowych tekstów stanisławowskich odnajdujemy również hymny, wykorzystujące stylizację biblijną. Przytoczę tu spośród nich dwa, napisane przez anonimowych Kurlandczyków bezpośrednio po zamachu na Stanisława Augusta, jakiego dokonali konfederaci barscy 3 listopada 1771 roku$^{28}$ : Ein Gesang am Dankfeste, wegen der Errettung des Königs (Piéśn zokazji śu'ę̧ta dzig̨kezźnie’nia za uratou'anie króla), na melodię protestanckiego chorału Marcina Lutra Ein feste Burg ist unser Gott (Warou'nq tu'ierdza jest nasz Bóg) oraz Hy'mmus auf die Errettung des Königs (Hymu na uratouranie króla), śpiewany na równie popularną melodię Gelobt seist du Jesu Christ (Podmu'alony bqd ̌́, Jezu Chryste'). Autor drugiego tekstu

\footnotetext{
${ }^{25}$ M. Klimowicz, op. cit., s. 220. Stąd tcż pozostate cytaty.

2h Cyt. za: ibidem. s. 11.

${ }^{27}$ F. Schulz, op. cit., s. 650)-651.

2s Ocena nie tylko poetyckich reakcji na zamach dokonany przez konfederatów i monarszą obronę „królobójców” z 2 sicrpnia 1773 zob. m. in. P. Ugnicwski, "Szkaradny u'ystępek króla" u' mį̣dzynarodon'ej propagandzic Stanistau'a An!gusta. .Przegląd Historyczny" 2005 t. 45 z. 3. s. 327-347; B. Wolska. Poe -ja polityczna cascón piern'szego rozbiorn i sejmu delegacyjnego 1772-1775. Wrochaw 1983, s. 121-137; cadem, Echa konfederacji barskiej u' okolic=nościourej literaturze politycznćj lut 1772-1775. „Napis” scria 3, 1997, s. 93-95: J. Wójcicki. Poctrekie reakeje mo ponwanic Stanistan'a Augnsta Poniaton'skiego, ibidem, seria 1, 1994, s. 83-112 (tam też spis tckstów źródlowych ze szczególnym uwzg̨lędnicnicm kodeksu z Biblioteki Czartoryskich sygn. 781).
} 
przedstawia Stanisława Augusta jako wladcę „szlachetnej krwi”, jako Bozego pomazańca, którego od śmierci „z rąk palających dzikim instynktem morderców” ocalić mógł jedynie Stwórca. Tekst ułożony „ın cincm Curländer” (..przez pewnego Kurlandczyka”) — który, jak donosiły „Mitauische Nachrichten”-29 w rubryce Atertissements, można było nabyć w Książęcej Drukarni Dworskiej - miał być śpiewany podczas nabożcístw dziękczynnych za szczęśliwe ocalenie królewskiego życia. A było ich w Mitawie i innych miastach Kurlandii i Semigalii, podobnie jak na terenic całej Rzeczypospolitej Obojga Narodów, wiele. W poniedzialek, 18 listopada 1771 roku, w numerze 92 owych „Mitawskich Wiadomości" donoszono z Mitawy:

Gestern (...) u'nurde in allen Kirchen dieser Hochfürstlichen Residenzstadt auf hödhst'n Befehl Sr. Hochfïrstlichen Durdhlanditen Lnseres gnädigst regierenden Herzoges und Landesherm, ein solemnes Dankfest, u'egen der u'underbaren Errettmng Sr. Majestät des Königs uon Pohlen ans der äussersten Lebensgefahr, gefeiert. Unsere Durchlanchtigste und gnädigste Landes-Herrschaft w'olnten dem Gottesdienst in der heiligen Dreifaltigkeitskirche bei, u'o sellst, nach einer, von der Hochfürstlichen Capelle anfgefiihrten schönen Music, der Herr Superintendents, Christian Hubn, ïber die aus Psalm 9, u. 2-15 inculus[ibe] genommene Worte, cine anf diese Foicrlichkeit verfertigte rïhrende Predigt hielt, nach der Endignng, „Das Herr Gott dich loben wir", wnter Panke'n und Trompeten Schall, abgesungen ward.

Wczoraj (...) na polecenie Jego Książęcej Mości, laskawie panującego nam Księcia i wladcy, odprawiono we wszystkich kościołach stolicy Księstwa uroczyste nabożeństwa dziękczynne za cudowne uratowanie życia Jego Królewskiej Mości Króla Polski z najgorszego nicbezpieczeństwa. Panujący nam laskawic dwór ksiązęcy aczestniczył w nabożeństwie odprawianym w kościcle św. Trójcy, gdzie po pięknej muzyce wykonanej przez orkiestrę dworską poruszające kazanie okolicznościowe wygłosił superintendent, p. Christian I Hube, na temat wzięty z psalmu 9, wersety od 2 do 15. Na zakoníczenie odśpiewano, przy dźwiękach bębnów i trąb, hymn „Ciebie, Boże, wychwalany”.

Następnic, jak podano, książę wydał wspanialy obiad, a wieczorem odbył się koncert w Wielkiej Sali dworu (przebudowanego przez Ernesta Birona na wzór Palacu Zimowego w Petersburgu). Trzy tygodnie później, 9 grudnia, ta sama gazeta, po zamieszczeniu informacji o uroczystych obchodach imienin Najjaśniejszej Imperatorowej, donosiła, iż dzień wcześniej odprawiono w obu kościołach libawskich nabożenstwa pochwalno-dziçkczynne,

\footnotetext{
2" "Mitauische Nachrichten von Staats- Gelchrten und Einheimischen Sachen mit gnädigster Feilıcit", 18 XI 1771 (cyt. za mikrofilmem Biblioteki Gdańskiej PAN sygn. 761: stąd takze cytat z grudniowego numeru periodyku).
} 
w czasie których głoszono wzruszające kazania, a w świątyni niemieckiej wykonano kantatę skomponowaną przez kantora Gaydę. Po odśpiewaniu „Te Dém!” oddano jednoczesny salut armatni przy kościołach i ze stojących w porcie okrętów. Wieczorem magistrat zorganizowal uroczysty obiad, na którym obecni byli miejscowi notable i oficerowie gwardii obywatelskiej.

Tyle oficjalne periodyki. Pora już na wnioski.

Okolicznościowa kurlandzka muza sięgała po znane „królewskie” motywy i wątki, głęboko zakorzenione w poetyce gatunku. W panegirycznym konterfekcie ukazuje się więc Poniatowski jako rex sapiens, (król mądry), res pacatorins (król niosący pokój), jako ojciec młodzieży czy opiekun nauk i sztuk, którego panowanie przywróciło w granicach Rzeczypospolitej złoty wiek. Przede wszystkim jednak jest on ukazany jako pomazaniec Boży, którego Stwórca otacza nieustanną opieką. Taki portret, ukochanego władcy, przynosi zarówno wierszowana laudacja, jak i pamiętnikarskie zapiski. Pozytywny wizermnek wychodzi spod piór środowiska dworskiego i naukowego. Odnajdıjemy go w relacji Fryderyka Schulza i Elisy von der Recke.

Polski władca odznaczył Orderem św. Stanisława, podobnie jak obywateli Rzeczypospolitej, wielı Kurlandczyków. Jednym z nich był królewski szambelan, Karl Heinrich von I Ieyking. W swych Wspommieniach z ostatnich lat Polski i Kurlandii ${ }^{30}$ przedstawil różne oblicza Poniatowskiego. Barona uważano powszechnie za amoralnego karierowicza, który, uświadamiając sobie słabości Rzeczypospolitej, dążył do przylączenia Kurlandii do Rosji, za co podobno otrzymal między innymi tabakierę wysadzaną brylantami.

Promowani i odznaczani orderami przez Stanisława Augusta mniej lub bardziej zdolni Kurlandczycy dziękowali mu za opiekę, inni zabiegali o monarsze względy. Na pewno najbliższy królowi przez długie lata był I terman Karl Keyselingk, „z pochodzenia Kurlandczyk, z serca kosmopolita"3!. Ambasador rosyjski został zatrudniony jako nauczyciel 12-letniego Stasia, i do chwili swej śmierci (w 1764 roku) darzyl do uczuciem przyjaźni ${ }^{32}$. Ponad trzydzieści lat później, z rozkazu Katarzyny II, Stanisława Augusta - na krótko przed abdykacją — powital w Grodnie Mikołaj Repnin, następca Keyserlingka na stanowisku ambasadora. Tytułowano go wówczas między innymi wielkorządcą Kurlandii (liczącej w 1795 roku „4(14266 dusz”33).

3" K. H. Heyking. op. cit.. s. 47-198. O jego dzialalności masońskicj zob. m. in.: K. Maliszewski. Kommmi-

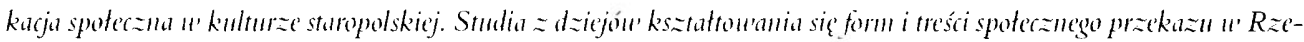
capospolitej szlacheckiej, Tormí 20(01, s. 126-127.

${ }^{31}$ K. Zicnkowska. Stunistau' Angust Poniatou'ski. Wroclaw 1998. s. 29.

32 A oto fragment królewskich wspomnicń (Stanistaw August Poniatowski, op. cit., s. 196) dotyczący rozmów. jakic toczyli obaj przed wyborem Poniatowskiego na polski tron: "Wick razy dyskutowalem dhugo z Kayserlingiem na temat libermm s'to. które pragnąl zachować (jak mówil) dia dobra Polski. Używatem argumentów jak najbardzicj oczywistych i logicznych. czego sam uczył mnic w dzieciństwic. zarzucając mu absurdalność jego rozumowania w świetle nauk. które mi w pajal. Jako przedstawicicl Rosji musial udawać, że nic rozunic. Nic micliśny innego wyjścia. jak ograniczyć nasze zapçdy w taki sposób, aby Kayserling w oczach wlasnego dworı mógl uchodzić za of iarę naszej przewrotności".

${ }^{33}$ Za: Encyklopedia pouszectma Orgelbranda, t. 16. Warszawa 1864. s. 481. 
W szkicu analizowałam jedynie poetyckie laudacje. To, że nie natrafilam na wiersze należące do oficjalnej literatury okolicznościowej, które kreślilyby negatywny portret Stanislawa Augusta Poniatowskiego, nie oznacza, że takowe na terenie polskiego lenna nie powstawały. Siostra Bironowej pisze co prawda o Poniatowskim jako o ,naszym" wladcy, ale w periodykach nie znajdzieny tego typu zwrotów. Za „naszego” uważa się księcia Birona, a o Stanisławie Auguście pisze się jako o „królı Polski”. Jedno nie ulega wątpliwości: obywatcle Korony wraz ze swym monarchą podzielili los mieszkańców Księstwa. W drugiej połowie XVIII wieku dokonywala się bowiem powolna „kurlandyzacja” Rzeczypospolitej. I nie tylko panegiryki znad Dźwiny o tym milczaly. 